\title{
Effects of N-3 Polyunsaturated Fatty Acids on Dementia
}

\author{
Hidekatsu Yanai
}

\begin{abstract}
$\mathrm{N}-3$ polyunsaturated fatty acids (PUFAs) including $\alpha$-linolenic acid (ALA), eicosapentaenoic acid (EPA) and docosahexaenoic acid (DHA) have anti-inflammatory effects and neuronal protective functions and may benefit prevention of dementia; however, the epidemiological evidence is very limited. Therefore, the literature about the association between n-3 PUFA and dementia was searched, by using Pubmed. In the analyses of observational studies, n-3 PUFA has been reported to be beneficially associated with dementia in 17 studies; however, the beneficial association between n-3 PUFA and dementia was denied by three studies. In the analyses of intervention studies, n-3 PUFA supplementation was beneficially associated with dementia in eight studies; however, five studies reported the negligible effect of n-3 PUFA for dementia. N-3 PUFA may improve Alzheimer's disease by increasing clearance of amyloid- $\beta$ peptide, neurotrophic and neuroprotective factors, and by anti-inflammatory effects. In conclusion, patients with mild memory and/or cognitive impairment can be treated by a long-term and higher intake of n-3 PUFA.
\end{abstract}

Keywords: Alzheimer's disease; Docosahexaenoic acid; Eicosapentaenoic acid; N-3 polyunsaturated fatty acids

\section{Introduction}

It has been considered that $\mathrm{n}-3$ polyunsaturated fatty acids (PUFAs) including $\alpha$-linolenic acid (ALA), eicosapentaenoic acid (EPA) and docosahexaenoic acid (DHA) have anti-atherosclerotic and anti-inflammatory effects and also neuronal protective functions and may benefit prevention of dementia; however, the epidemiological evidence is limited. Furthermore, there is a lack of consensus on the benefits of EPA and DHA supplementations on cognition in dementia and/or Alzheimer's disease (AD) elderly. An National Institutes of Health (NIH) State of the Science Conference panel concluded in 2010 that insufficient evidence is available to recommend the use of any primary prevention therapy for AD or cognitive

Manuscript accepted for publication November 11, 2016

Department of Internal Medicine, National Center for Global Health and Medicine Kohnodai Hospital, 1-7-1 Kohnodai, Ichikawa, Chiba 272-0034, Japan. Email: dyanai@hospk.ncgm.go.jp

doi: https://doi.org/10.14740/jocmr2815w decline with age [1]. Therefore, the literatures were reviewed to find whether serum n-3 PUFAs are associated with risk of dementia.

\section{The Search Strategy and the Results}

The literature about the association between n-3 PUFA and dementia was searched, by using Pubmed. Eighty-nine, 206 and 398 articles were found by using "EPA and dementia", "DHA and dementia" and "n-3 PUFA and dementia and human or omega-3 PUFA and dementia and human" as the keywords, respectively. After the review of the literatures, articles were divided into "observational studies", "intervention studies" and "the underlying mechanisms for n-3 PUFA-mediated improvement or prevention of dementia".

\section{The Observational Studies Which Investigated the Association Between N-3 PUFA and Demen- tia}

The observational studies which assessed the association between n-3 PUFA and dementia are shown in Table 1 [2-21]. Recently, Yamagishi et al performed an intra-cohort casecontrol study nested in a community-based cohort, involving 7,586 Japanese individuals aged 40 - 74 years. Serum ALA, EPA, and DHA were measured in 315 cases of incident disabling dementia.

Serum ALA level was inversely associated with risk of disabling dementia. However, associations of EPA and DHA with disabling dementia were not statistically significant [2]. ALA, but not EPA and DHA, was also associated with reduction of the risk for mild dementia among the Korean elderly [3]. In the Invecchiare in Chianti study where plasma fatty acids (FAs) were measured by gas chromatography in 935 community-dwelling older persons from the population of two towns near Florence, Italy, dementia is associated with low plasma n-3 PUFA relative concentrations, especially low plasma ALA concentrations [4]. Recent studies demonstrated a significant association of ALA with dementia.

In the Mayo Clinic Study of Aging, the odds ratio of mild cognitive impairment (MCI) decreased with increasing n-3 PUFA intake [5]. The top quartile of plasma phosphatidylcholine DHA level was associated with a significant $47 \%$ reduction in the risk of developing all-cause dementia in the Framingham Heart Study [6]. In the Cardiovascular Health Cognition Study, consumption of fatty fish was associated 
Table 1. The Observational Studies Which Assessed the Association Between N-3 PUFA and Dementia

\begin{tabular}{lll}
\hline Authors & Study design & Subjects \\
\hline $\begin{array}{l}\text { Yamagishi } \\
\text { et al [2] }\end{array}$ & $\begin{array}{l}\text { Community-based nested case- } \\
\text { control study }\end{array}$ & $\begin{array}{l}315 \text { cases of incident disabling } \\
\text { dementia }\end{array}$ \\
& & \\
Kim et al [3] & Cross-sectional study & $\begin{array}{l}57 \text { elderly (age } \geq 65 \\
\text { years) patients }\end{array}$ \\
& & $\begin{array}{l}\text { 935 community-dwelling older } \\
\text { persons }\end{array}$ \\
\hline
\end{tabular}

\section{Results/conclusions}

Serum ALA was inversely associated with risk of disabling dementia: the multivariate odds ratios $(95 \% \mathrm{CI})$ were $0.57(0.39-0.85), 0.51$ $(0.34-0.76)$, and $0.61(0.41-0.90)$ for persons with the second, third, and highest quartiles of ALA, respectively, as compared with the lowest quartile ( $\mathrm{P}$ for trend $=0.01$ ).

Multivariate-adjusted regression analysis showed that a higher level of ALA significantly decreased the risk of mild dementia after adjusting for age, sex, and height.

After adjustment for age, gender, education, body mass index, weight loss, smoking status, cholesterol and triglycerides levels, daily intake of alcohol, FA and total energy, cardiovascular disease, depression and other FA levels, participants with dementia had significantly lower n-3 PUFA levels $(2.9 \%$ vs. $3.2 \% ; \mathrm{P}<0.05)$, particularly ALA levels $(0.34 \%$ vs. $0.39 \% ; \mathrm{P}<0.05)$, than did participants with normal cognitive function.

Roberts et al Cross-sectional study

[5]

Schaefer et al Prospective follow-up study

[6]

Huang et al Cross-sectional study

[7]

Crt

1,233 non-demented subjects aged $\geq 70$ years

899 men and women who were free of dementia at baseline, had a median age of 76.0 years, and were followed up for a mean of 9.1 years

Subjects who participated in the Cardiovascular Health Cognition Study (CHCS)

815 residents, aged 65 - 94 years, who were initially unaffected by $\mathrm{AD}$

[8]

Prospective study conducted from 1993 through 2000, of a stratified random sample from a geographically defined community

Morris et al [9] Cross-sectional analyses of deceased participants in the Memory and Aging Project clinical neuropathological cohort study, 2004 - 2013

van de Rest Longitudinal, communityet al [10] based epidemiologic study of aging and dementia (the Rush Memory and Aging Project)

Lopez et al Case-cohort study
[11]

Tully et al Case-control study
$[12]$
cognitive assessment and dietary
554 deceased participants $(51.6 \%)$. The mean (SD) age at death was $89.9(6.1)$ years, $67 \%$ (193) were women, and the mean (SD) educational attainment was 14.6 (2.7) years.

915 participants (age $81.4 \pm$ 7.2 years, $25 \%$ men) who had completed at least one follow-up data

266 community dwelling men and women aged 67 - 100 years $($ mean $=80.2)$

The subjects (119 females and 29 males) aged 76.5 (SD 6.6) years had an MMSE score of 19.5 (SD 4.8). The control subjects (36 females and 9 males) aged 70 (SD 6.0) years were not cognitively impaired (MMSE score $>24$ )
Compared to the lowest tertile, the OR $(95 \% \mathrm{CI})$ for the upper tertiles were $0.62(0.42-0.91$; P for trend $=0.012)$ for $n-3$ PUFA after adjustment for age, sex, number of years of education, and caloric intake.

The top quartile of plasma phosphatidylcholine DHA level was associated with a significant $47 \%$ reduction in the risk of developing all-cause dementia.

Although consumption of lean fried fish had no protective effect, consumption of fatty fish more than twice per week was associated with a reduction in risk of dementia by $28 \%(95 \%$ CI: $0.51-1.02)$, and $\mathrm{AD}$ by $41 \%(95 \% \mathrm{CI}: 0.36-0.95)$ in comparison to those who ate fish less than once per month. Stratification by APOE epsilon 4 showed this effect to be selective to those without the epsilon4 allele.

Participants who consumed fish once per week or more had $60 \%$ less risk of $\mathrm{AD}$ compared with those who rarely or never ate fish (RR: 0.4; $95 \% \mathrm{CI}: 0.2-0.9)$ in a model adjusted for age and other risk factors. Total intake of n-3 PUFA was associated with reduced risk of AD, as was intake of DHA. EPA was not associated with AD.

In models adjusted for age, sex, education, and total energy intake, seafood consumption ( $\geq 1 \mathrm{meal}(\mathrm{s}) /$ week) was significantly correlated with less $\mathrm{AD}$ pathology including lower density of neuritic plaques $(\beta=$ -0.69 score units (95\% CI: -1.34 to -0.04$)$ ), less severe and widespread neurofibrillary tangles $(\beta=-0.77$ score units $(95 \% \mathrm{CI}:-1.52$ to -0.02$)$ )

Consumption of seafood was associated with slower decline in semantic memory $(\beta=0.024 ; \mathrm{P}=0.03)$ and perceptual speed $(\beta=$ $0.020 ; \mathrm{P}=0.05$ ) in separate models adjusted for age, sex, education, participation in cognitive activities, physical activity, alcohol consumption, smoking, and total energy intake. In secondary analyses, APOE\&4 carriers demonstrated slower rates of decline in global cognition and in multiple cognitive domains with weekly seafood consumption and with moderate to high n-3 PUFA intake from food. Plasma DHA in the highest tertile was associated with a $65 \%$ reduced odds of all-cause dementia (95\% CI: 0.17 - 0.92) and a $60 \%$ reduced odds of AD ( $95 \%$ CI: $0.15-1.10)$. Dietary DHA in the highest tertile was associated with a $73 \%$ reduced odds of all-cause dementia $(95 \%$ CI: $0.09-0.79)$ and a $72 \%$ reduced odds of AD (95\% CI: $0.09-0.93)$.

Serum cholesteryl ester-EPA and DHA levels were significantly lower ( $\mathrm{P}<0.05$ and $\mathrm{P}<0.001$, respectively) in all MMSE score quartiles of patients with AD compared with control values. Serum cholesteryl ester-DHA levels were progressively reduced with severity of clinical dementia. Step-wise multiple regression analysis showed that cholesteryl ester-DHA was the important determinants of MMSE score. 
Table 1. The Observational Studies Which Assessed the Association Between N-3 PUFA and Dementia - (continued)

\begin{tabular}{|c|c|c|c|}
\hline Authors & Study design & Subjects & Results/conclusions \\
\hline $\begin{array}{l}\text { Conquer et al } \\
{[13]}\end{array}$ & Cross-sectional study & $\begin{array}{l}\text { Patients with AD, OD, or CIND } \\
\text { and compared them with a group } \\
\text { of elderly control subjects with } \\
\text { normal cognitive functioning }\end{array}$ & $\begin{array}{l}\text { Plasma phospholipid and PC levels of DHA, total n- } 3 \text { PUFA, and the } \\
\text { n-3/n- } 6 \text { ratio were lower in the AD, OD, and CIND groups. In the } \\
\text { plasma PE fraction, levels of DHA and the total n-3 PUFA levels were } \\
\text { significantly lower in the AD, OD, and CIND groups. }\end{array}$ \\
\hline $\begin{array}{l}\text { Whalley et al } \\
{[14]}\end{array}$ & Observational follow-up study & $\begin{array}{l}120 \text { volunteers, born in } 1936, \text { at } \\
\text { approximate ages of } 64,66, \\
\text { and } 68 \text { years }\end{array}$ & $\begin{array}{l}\text { Total n-3 PUFA and DHA concentrations were associated with benefits } \\
\text { for cognition at approximately } 64 \text { years old and from approximately } \\
64 \text { to approximately } 68 \text { years old. After adjustment for sex, APOE } \\
\text { epsilon } 4 \text { status, and intelligence quotient at } 11 \text { years old, the effects } \\
\text { associated with total n-3 PUFA remained significant. }\end{array}$ \\
\hline $\begin{array}{l}\text { Nishihira et al } \\
{[15]}\end{array}$ & Cross-sectional study & $\begin{array}{l}185 \text { participants (mean age } 84.1 \\
\pm 3.4 \text { years) assessed in } 2011 \text { who } \\
\text { were free from frank dementia }\end{array}$ & $\begin{array}{l}\text { Serum DHA levels decreased with increasing age }(P=0.04) \text {. Higher } \\
\text { global cognitive function was associated with higher levels of serum } \\
\text { EPA }(P=0.03) \text { and DHA }+ \text { EPA }(P=0.03) \text { after controlling for } \\
\text { confounders. }\end{array}$ \\
\hline $\begin{array}{l}\text { Ammann et al } \\
{[16]}\end{array}$ & Retrospective cohort study & $\begin{array}{l}2,157 \text { women with normal } \\
\text { cognition enrolled in a clinical } \\
\text { trial of postmenopausal hormone } \\
\text { therapy }\end{array}$ & $\begin{array}{l}\text { No association between RBC DHA + EPA levels and age-associated } \\
\text { cognitive decline was found, in a cohort of older, dementia-free women. }\end{array}$ \\
\hline $\begin{array}{l}\text { Phillips et al } \\
\text { [17] }\end{array}$ & Cross-sectional study & $\begin{array}{l}135 \text { individuals aged between } 55 \\
\text { and } 91 \text { years }(19 \mathrm{AD}, 55 \mathrm{CIND} \text {, } \\
\text { and } 61 \mathrm{HV})\end{array}$ & $\begin{array}{l}\text { Across the whole sample, and after controlling for age, years of } \\
\text { education, level of socio-economic deprivation, and gender, n-3 PUFA } \\
\text { intake, plasma PC DHA, and plasma PC EPA were all significant } \\
\text { positive predictors of memory functioning. }\end{array}$ \\
\hline $\begin{array}{l}\text { Feart et al } \\
{[18]}\end{array}$ & $\begin{array}{l}\text { Cross-sectional analysis of the } \\
\text { association between plasma } \\
\text { FA and a Mediterranean } \\
\text { diet (MeDi) adherence was } \\
\text { performed by multi-linear } \\
\text { regression }\end{array}$ & $\begin{array}{l}\text { The study population (mean age } \\
75.9 \text { years) consisted of } 1,050 \\
\text { subjects from Bordeaux (France) } \\
\text { included in the Three-City cohort }\end{array}$ & $\begin{array}{l}\text { The protective effect of the MeDi on cognitive functions might be } \\
\text { mediated by higher plasma DHA and lower n-6/n-3 PUFA ratios. }\end{array}$ \\
\hline $\begin{array}{l}\text { Kroger et al } \\
{[19]}\end{array}$ & $\begin{array}{l}\text { Cohort study of a representative } \\
\text { sample of persons aged } \geq 65 \\
\text { years }\end{array}$ & $\begin{array}{l}663 \text { non-demented subjects, } \\
149 \text { incident cases of dementia, } \\
\text { including } 105 \text { with AD. }\end{array}$ & $\begin{array}{l}\text { In adjusted Cox regression models with age as the time scale, there } \\
\text { were no associations between total n-3 PUFA, DHA, or EPA and } \\
\text { dementia or AD. }\end{array}$ \\
\hline $\begin{array}{l}\text { Devore et al } \\
{[20]}\end{array}$ & $\begin{array}{l}\text { Age- and sex-adjusted Cox } \\
\text { proportional hazard and } \\
\text { multivariate-adjusted models } \\
\text { to evaluate the relative risk } \\
\text { of dementia and AD across } \\
\text { categories of typical fish intake } \\
\text { and fish type consumed }\end{array}$ & $\begin{array}{l}5,395 \text { participants aged } \geq 55 \\
\text { years in the Rotterdam Study } \\
\text { who were free of dementia and } \\
\text { reported dietary information at } \\
\text { baseline }\end{array}$ & $\begin{array}{l}\text { During an average follow-up of } 9.6 \text { years, dementia developed in } 465 \\
\text { participants ( } 365 \text { with AD). In multivariate-adjusted models, total fish } \\
\text { intake was unrelated to dementia risk (P for trend }=0.7 \text { ). Compared } \\
\text { with participants who typically ate no fish, those with a high fish intake } \\
\text { had a similar dementia risk (HR: } 0.95 ; 95 \% \text { CI: } 0.76-1.19 \text { ), as did } \\
\text { those who typically ate fatty fish (HR: } 0.98 ; 95 \% \text { CI: } 0.77-1.24) \text {. } \\
\text { Dietary intakes of n-3 PUFA were also not associated with dementia } \\
\text { risk. }\end{array}$ \\
\hline $\begin{array}{l}\text { Samieri et al } \\
{[21]}\end{array}$ & $\begin{array}{l}\text { Of non-demented participants } \\
\text { who were followed up for } 4 \\
\text { years, } 65 \text { developed dementia. } \\
\text { The association between the } \\
\text { proportion of plasma FA at } \\
\text { baseline and the risk of incident } \\
\text { dementia was assessed by } \\
\text { multivariate proportional } \\
\text { hazard models, taking into } \\
\text { account depressive status }\end{array}$ & $\begin{array}{l}1,214 \text { non-demented participants } \\
\text { in the Three-City Study from } \\
\text { Bordeaux (France) }\end{array}$ & $\begin{array}{l}\text { A higher plasma EPA concentration was associated with a lower } \\
\text { incidence of dementia (HR: } 0.69 ; 95 \% \text { CI: } 0.48-0.98) \text {, independently } \\
\text { of depressive status. The relations between DHA, total n-3 PUFA, and } \\
\text { incident dementia did not remain significant in multivariate models. } \\
\text { Higher ratios of AA to DHA and of n- } 6 \text { to n-3 FA were related to an } \\
\text { increased risk of dementia, particularly in depressive subjects }(\mathrm{n}=90) \text { : } \\
\text { ratio of AA to DHA (HR: } 2.65 ; 95 \% \text { CI: } 1.07-6.56) \text { and ratio of n- } 6 \text { to } \\
\text { n-3 (HR: } 1.61 ; 95 \% \text { CI: } 1.04-2.47) \text {. }\end{array}$ \\
\hline
\end{tabular}

AA: arachidonic acid; AD: Alzheimer's disease; ALA: a-linolenic acid; Cl: confidence interval; CIND: cognitive impairment no dementia; DHA: docosahexaenoic acid; EPA: eicosapentaenoic acid; FA: fatty acids; HR: hazard ratio; HV: healthy volunteers; OD: other dementias; OR: odds ratio; PC: phosphatidylcholine; PE: phosphatidylethanolamine; PUFA: polyunsaturated fatty acids; RBC: red blood cell; RR: relative risk.

with a reduced risk of dementia and $\mathrm{AD}$ for those without the APOE epsilon4 (APOE\&4) allele [7]. In the prospective study conducted from 1993 through 2000, dietary intake of n-3 PUFA and weekly consumption of fish were associated with reduction of the risk of incident AD [8]. In cross-sectional analyses, moderate seafood consumption was correlated with lesser AD neuropathology [9]. An ongoing longitudinal, community-based epidemiological study of aging and demen- tia suggested protective relations of one meal per week of seafood and n-3 PUFA against decline in multiple cognitive domains [10].

In the case-cohort study, plasma and dietary DHA were associated with protection against dementia [11]. The casecontrol study showed that serum cholesteryl ester-DHA levels were progressively reduced with severity of clinical dementia and were the important determinants of mini-mental 
state examination (MMSE) score [12]. Plasma phospholipid, phosphatidylcholine and phosphatidylethanolamine levels of DHA, total n-3 PUFA, and the n-3/n-6 ratio were lower in the $\mathrm{AD}$, other dementias, and cognitive impairment no dementia (CIND) groups [13]. In an observational follow-up study, total n-3 PUFA and DHA concentrations were associated with benefits for cognition at approximately 64 years old [14]. After adjustment for sex, APOE\&4 status, and intelligence quotient at 11 years old, the effects associated with total n-3 PUFA remained significant.

In the cross-sectional study using the data from the Keys to Optimal Cognitive Aging (KOCOA) study, an ongoing cohort of relatively healthy volunteers aged over 80 years old, living in Okinawa, Japan, higher serum EPA and DHA + EPA levels were independently associated with better scores on global cognitive function among the oldest old, free from dementia [15]. In the retrospective cohort study, an association between red blood cell (RBC) DHA + EPA levels and age-associated cognitive decline was not observed in a cohort of older, dementia-free women [16]. The study which investigated differences in dietary intake and blood plasma content of EPA and DHA in individuals with CIND, AD and healthy volunteers (HVs), showed the possibility that n-3 PUFA has an impact on cognitive decline [17]. Higher adherence to a Mediterranean diet (MeDi) and n-3 PUFA may contribute to decreased dementia risk. In the study which investigated the relationship between plasma FA and MeDi adherence suggested that the protective effect of the MeDi on cognitive functions might be mediated by higher plasma DHA and lower n-6/n-3 PUFA ratio [18].

In a cohort study of a representative sample of persons aged $\geq 65$ years, conducted from 1991 to 2002, no associations between n-3 PUFA and dementia or AD were found [19]. Devore et al studied the dietary consumption of fish and n-3 PUFA in relation to long-term (an average follow-up of 9.6 years) dementia risk, by using 5,395 participants aged $\geq 55$ years in the Rotterdam Study who were free of dementia and reported dietary information at baseline. In this Dutch cohort, a moderate consumption of fish and n-3 PUFA do not appear to be associated with long-term dementia risk [20]. Of 1,214 nondemented participants in the Three-City Study from Bordeaux (France) who were followed up for 4 years, 65 participants developed dementia. The association between the proportion of plasma FA at baseline and the risk of incident dementia was assessed by multivariate proportional hazard models, taking into account depressive status. A high plasma EPA concentration may decrease the risk of dementia, whereas high ratios of n-6 to n-3 PUFA and of arachidonic acid (AA) to DHA may increase the risk of dementia, especially in depressed older persons [21].

In the analyses of observational studies, three studies reported a significant association between ALA and dementia. N-3 PUFA, DHA, DHA + EPA, and EPA have been reported to be significantly associated with dementia, in two, five, two, and one studies, respectively; however, the association between DHA + EPA and dementia was denied by one study. Fish or seafood intake was beneficially associated with dementia in four studies; however, one article challenged such association.

\section{The Intervention Studies Which Investigated the Association Between N-3 PUFA and Dementia}

The intervention studies which assessed the association between n-3 PUFA and dementia are shown in Table 2 [2234]. In a randomized, double-blind, placebo-controlled trial (RCT), healthy older adults with subjective memory impairment were allocated to fish oil group or placebo group for 24 weeks. EPA and DHA supplementation increases RBC n-3 PUFA content, working memory performance, and blood oxygen level-dependent signal in the posterior cingulate cortex during greater working memory load in older adults with subjective memory impairment [22]. However, another RCT confirmed an overall negligible benefit of n-3 PUFA supplementation for individuals with CIND or AD [23]. Eriksdotter et al demonstrated the dose-response relationships between plasma levels of n-3 PUFA and preservation of cognition [24]. The large intervention study showed no effect of dietary doses of n-3 PUFA on global cognitive decline in coronary heart disease patients [25].

A 6-month RCT showed that increased intakes of DHA and EPA benefited mental health in older people with MCI, and increasing n-3 PUFA intakes may reduce depressive symptoms and the risk of progressing to dementia [26]. In RCT, patients with $\mathrm{AD}$ received $1.7 \mathrm{~g}$ of DHA and $0.6 \mathrm{~g}$ of EPA or placebo $0.6 \mathrm{~g}$ of linoleic acid per day for 6 months. After 6 months, all patients received DHA and EPA for another 6 months. A DHA-enriched n-3 PUFA supplement may positively affect weight and appetite in patients with mild to moderate AD. Not carrying the APOE\&4 allele and high DHA were independently associated with weight gain [27].

An RCT involving 302 cognitively healthy (MMSE score $>21$ ) individuals aged 65 years or older was performed to investigate the effect of EPA and DHA supplementation on cognitive performance. Participants were randomly assigned to $1,800 \mathrm{mg}$ /day EPA-DHA, $400 \mathrm{mg}$ /day EPA-DHA, or placebo capsules for 26 weeks. No overall effect of 26 weeks of EPA and DHA supplementation on cognitive performance was observed [28].

In an RCT where $204 \mathrm{AD}$ patients ( $74 \pm 9$ years) with acetylcholine esterase inhibitor treatment and an MMSE > 15 points were randomized to daily intake of $1.7 \mathrm{~g} \mathrm{DHA}$ and $0.6 \mathrm{~g}$ EPA or placebo for 6 months. Supplementation with n-3 PUFA in patients with mild to moderate AD did not result in marked effects on neuropsychiatric symptoms except for possible positive effects on depressive symptoms in nonAPOE $\varepsilon 4$ carriers and agitation symptoms in APOE $\varepsilon 4$ carriers [29].

Recall of object locations was significantly better after $n-3$ PUFA $(2,200 \mathrm{mg} /$ day $)$ supplementation compared with placebo [30]. A 24-week n-3 PUFA (1.8 g/day) treatment showed a significant improvement in AD assessment scale compared to the placebo group in participants with MCI, which was not observed in those with $\mathrm{AD}$ [31].

In Japan, participants in elderly care facilities and nursing homes were randomized in active and placebo groups [32]. This study suggested that DHA-enriched meals protect against age-related cognitive decline, and also improve apathy and 
Table 2. The Intervention Studies Which Assessed the Association Between N-3 PUFA and Dementia

\begin{tabular}{|c|c|c|c|}
\hline Authors & $\begin{array}{l}\text { Duration and dose } \\
\text { of n-3 PUFA }\end{array}$ & Subjects & Severity of dementia \\
\hline $\begin{array}{l}\text { Boespflug } \\
\text { et al [22] }\end{array}$ & $\begin{array}{l}\text { Fish oil }(\text { EPA + DHA: } 2.4 \\
\text { g/day, } \mathrm{n}=11) \text { or placebo } \\
(\text { corn oil, } \mathrm{n}=10) \text { for } 24 \\
\text { weeks }\end{array}$ & $\begin{array}{l}\text { Healthy older adults } \\
\text { ( } 62 \text { - } 80 \text { years) with } \\
\text { subjective memory } \\
\text { impairment }\end{array}$ & $\begin{array}{l}\text { Subjective memory } \\
\text { impairment, but not } \\
\text { meeting criteria for } \\
\text { MCI or dementia }\end{array}$ \\
\hline
\end{tabular}

\begin{tabular}{|c|c|}
\hline $\begin{array}{l}\text { Phillips } \\
\text { et al [23] }\end{array}$ & $\begin{array}{l}\text { N-3 PUFA ( } 600 \mathrm{mg} \text { EPA } \\
\text { and } 625 \mathrm{mg} \text { DHA per day) } \\
\text { or placebo (olive oil) over } \\
\text { a 4-month period }\end{array}$ \\
\hline $\begin{array}{l}\text { Eriksdotter } \\
\text { et al [24] }\end{array}$ & $\begin{array}{l}\text { Daily intake of } 2.3 \mathrm{~g} \mathrm{n}-3 \\
\text { PUFA or placebo for } 6 \\
\text { months; subsequently all } \\
\text { received the n- } 3 \text { PUFA for } \\
\text { the next } 6 \text { months }\end{array}$ \\
\hline $\begin{array}{l}\text { Geleijnse } \\
\text { et al [25] }\end{array}$ & $\begin{array}{l}400 \mathrm{mg} / \text { day of EPA-DHA, } \\
2 \mathrm{~g} / \text { day of ALA, both } \\
\text { EPA-DHA and ALA, or } \\
\text { placebo for } 40 \text { months }\end{array}$ \\
\hline $\begin{array}{l}\text { Sinn et al } \\
{[26]}\end{array}$ & $\begin{array}{l}\text { EPA }(1.67 \mathrm{~g} \text { EPA }+0.16 \mathrm{~g} \\
\mathrm{DHA} / \mathrm{day} ; \mathrm{n}=17), \mathrm{DHA} \\
(1.55 \mathrm{~g} \text { DHA }+0.40 \mathrm{~g} \\
\text { EPA/day; } \mathrm{n}=18) \text { or the } \\
\mathrm{n}-6 \text { PUFA, LA }(\mathrm{LA} ; 2.2 \mathrm{~g} / \\
\text { day; } \mathrm{n}=15) \text { for } 6 \text { months }\end{array}$ \\
\hline $\begin{array}{l}\text { Irving et al } \\
\text { [27] }\end{array}$ & $\begin{array}{l}1.7 \mathrm{~g} \text { of DHA and } 0.6 \mathrm{~g} \text { of } \\
\text { EPA }(\mathrm{n}=89) \text { or placebo } \\
0.6 \mathrm{~g} \text { of LA per day }(\mathrm{n}= \\
85) \text { for } 6 \text { months }\end{array}$ \\
\hline
\end{tabular}

57 participants with $\quad$ CIND and AD
CIND and 19 with
AD
$\begin{aligned} & 174 \text { AD patients } \\ & (74 \pm 9 \text { years })\end{aligned}$

2,911 coronary patients $(78 \% \mathrm{men})$ aged 60 - 80 years

50 people aged $>65 \quad \mathrm{MCI}$ years with MCI

204 patients (aged $73 \pm 9,52 \%$ women) with AD.
Mild to moderate AD

MMSE score, 28.2 28.4

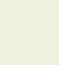


Table 2. The Intervention Studies Which Assessed the Association Between N-3 PUFA and Dementia - (continued)

\begin{tabular}{|c|c|c|c|c|}
\hline Authors & $\begin{array}{l}\text { Duration and dose } \\
\text { of n-3 PUFA }\end{array}$ & Subjects & Severity of dementia & Results/conclusions \\
\hline $\begin{array}{l}\text { Chiu et al } \\
{[31]}\end{array}$ & $\begin{array}{l}\mathrm{N}-3 \text { PUFA } 1.8 \mathrm{~g} / \text { day or } \\
\text { placebo (olive oil) for } 24 \\
\text { weeks }\end{array}$ & $\begin{array}{l}23 \text { participants with } \\
\text { mild or moderate } \\
\text { AD and } 23 \text { with } \\
\text { MCI }\end{array}$ & $\mathrm{AD}$ and $\mathrm{MCI}$ & $\begin{array}{l}\text { The treatment group showed better improvement } \\
\text { on the Clinician's Interview-Based Impression of } \\
\text { Change Scale than those in the placebo group over } \\
\text { the } 24 \text {-week follow-up ( } \mathrm{P}=0.008) \text {. There was no } \\
\text { significant difference in the cognitive portion of } \\
\text { the Alzheimer's disease assessment scale (ADAS- } \\
\text { cog) change during follow-up in these two groups. } \\
\text { However, the n-3 PUFA group showed significant } \\
\text { improvement in ADAS-cog compared to the placebo } \\
\text { group in participants with MCI }(\mathrm{P}=0.03) \text {, which was } \\
\text { not observed in those with AD. Higher proportions of } \\
\text { EPA on RBC membranes were also associated with } \\
\text { better cognitive outcome }(\mathrm{P}=0.003) \text {. }\end{array}$ \\
\hline $\begin{array}{l}\text { Yurko- } \\
\text { Mauro et } \\
\text { al [33] }\end{array}$ & $\begin{array}{l}900 \mathrm{mg} / \text { day of DHA and } \\
\text { placebo for } 24 \text { weeks }\end{array}$ & $\begin{array}{l}485 \text { healthy subjects, } \\
\text { aged } \geq 55 \text { with } \\
\text { MMSE }>26\end{array}$ & MMSE $>26$ & $\begin{array}{l}\text { Intention-to-treat analysis demonstrated significantly } \\
\text { fewer PAL six pattern errors with DHA versus } \\
\text { placebo at } 24 \text { weeks (difference score, }-1.63 \pm \\
0.76(95 \% \text { CI: }-3.1 \text { to }-0.14), \mathrm{P}=0.03) \text {. DHA } \\
\text { supplementation was also associated with improved } \\
\text { immediate and delayed verbal recognition memory } \\
\text { scores }(\mathrm{P}<0.02) \text {, but not working memory or } \\
\text { executive function tests. Plasma DHA levels doubled } \\
\text { and correlated with improved PAL scores }(\mathrm{P}<0.02) \\
\text { in the DHA group. }\end{array}$ \\
\hline
\end{tabular}

AD: Alzheimer's disease; ALA: a-linolenic acid; AVLT: auditory verbal learning test; CIND: cognitive impairment no dementia; DHA: docosahexaenoic acid; EPA: eicosapentaenoic acid; GDS; geriatric depression scale; LA: linoleic acid; MCl: mild cognitive impairment; MMSE: mini-mental state examination (scores < 24 are indicative for impaired cognitive functioning, and the maximum possible score on the MMSE test is 30); PAL: paired associate learning; PUFA: polyunsaturated fatty acids; RBC: red blood cell.

caregiver burden for the oldest-elderly Japanese with cognitive impairment. The 24-week supplementation with $900 \mathrm{mg}$ /day DHA improved learning and memory function in age-related cognitive decline [33]. However, supplementation with algal DHA compared with placebo did not slow the rate of cognitive and functional decline in patients with mild to moderate AD [34].

In the analyses of intervention studies, n-3 PUFAs have been reported to improve dementia in three studies. EPA + DHA supplementation was beneficially associated with dementia in three studies; however, four studies reported the negligible effects of EPA + DHA for dementia. DHA was favorably associated with dementia in two studies, however, which was challenged by one article.

\section{The Underlying Mechanisms for N-3 PUFA-Me- diated Improvement of Dementia}

The accumulation of neurotoxic amyloid- $\beta$ peptide $(A \beta)$ is a pathologically profound characteristic of $\mathrm{AD}[35-40]$. $\mathrm{A} \beta$ is derived from amyloid precursor protein (APP) [41]. APP is cleaved by $\alpha$-secretases within the A $\beta$ domain to produce $\alpha$-secretasecleaved soluble APP ( $\mathrm{SAPP} \alpha)$. sAPP $\alpha$ is neurotrophic and neuroprotective and enhancing APP processing by $\alpha$-secretases [42, 43]. EPA and DHA are able to increase membrane fluidity and 
Table 3. Characteristics of Patients Whose Dementia Can Be Improved or Prevented by N-3 PUFA

1. Mild memory and/or cognitive impairment

a) Subjective memory impairment

b) Mild cognitive impairment (MCI)

c) Cognitive impairment no dementia (CIND)

d) Mild Alzheimer's disease

2. Higher intake of fish

3. Additional daily n-3 PUFA intake $>2.0 \mathrm{~g}$

4. Additional daily DHA intake $>900 \mathrm{mg}$

5. Duration of treatment $>6$ months

lead to increase in sAPP $\alpha$ secretion [44]. Transthyretin (TTR) binds $A \beta$ and may reduce brain $A \beta$. N-3 PUFA treatment appeared to increase plasma-TTR in patients with AD [45]. N-3 PUFA is associated with enhancing clearance of $A \beta$.

Hjorth et al reported that DHA and EPA can be beneficial in $\mathrm{AD}$ by enhancing removal of $\mathrm{A} \beta$, increasing neurotrophin production, and decreasing pro-inflammatory cytokine production [46].

$\mathrm{AD}$ is associated with brain inflammation and reduced levels of specialized proresolving mediators (SPMs) which are derivatives of n-3 and n-6 PUFA and induce resolution of inflammation. Supplementation with n-3 PUFA for 6 months prevented a reduction in SPMs released from peripheral blood mononuclear cells (PBMCs) of AD patients [47]. Serini et al treated in vitro phytohemagglutinin (PHA)- or lipopolysaccharide (LPS)-stimulated PBMC from AD patients and agematched healthy controls with EPA or DHA. The addition of both EPA and DHA markedly reduced the cytokine release [48].

Prostaglandin F-2 $\alpha$ release from LPS-stimulated PBMC from $\mathrm{AD}$ patients was significantly diminished by a DHA-rich fish oil as compared with placebo. Prostaglandin F-2 $\alpha$ changes were correlated inversely with changes in plasma DHA and EPA. Decreased IL-6 and IL-1 $\beta$ levels correlated with decreased prostaglandin F-2 $\alpha$ levels [49].

Isoform-specific protein kinase $\mathrm{C}$ (PKC) activators may be useful as therapeutic agents for the treatment of AD. Three new epsilon-specific PKC activators (AA-CP4, EPA-CP5, and DHA-CP6), made by cyclopropanation (CP) of PUFA, have been developed. DHA-CP6 reduced the intracellular and secreted levels of $A \beta$ by $60-70 \%$ [50]. AD patients treated with DHA-rich n-3 PUFA supplementation increased their plasma concentrations of DHA (and EPA), which were associated with reduced release of IL-1 $\beta$, IL-6, and granulocyte colony-stimulating factor from PBMC [51].

N-3 PUFA may improve AD by increasing clearance of $\mathrm{A} \beta$, neurotrophic and neuroprotective factors, and by anti-inflammatory effects.

\section{Limitation of Present Study}

Only one database (Pubmed) was searched for articles to be reviewed.

\section{Conclusion}

Characteristics of patients whose dementia can be improved or prevented by n-3 PUFA are shown in Table 3. Patients with mild memory and/or cognitive impairment can be treated by a long-term and higher intake of n-3 PUFA.

\section{Conflicts of Interest}

The author declares that he has no conflicts of interest concerning this article.

\section{References}

1. Dacks PA, Shineman DW, Fillit HM. Current evidence for the clinical use of long-chain polyunsaturated n-3 fatty acids to prevent age-related cognitive decline and Alzheimer's disease. J Nutr Health Aging. 2013;17(3):240251.

2. Yamagishi K, Ikeda A, Chei CL, Noda H, Umesawa M, Cui R, Muraki I, et al. Serum alpha-linolenic and other omega-3 fatty acids, and risk of disabling dementia: Community-based nested case-control study. Clin Nutr. 2016.

3. Kim M, Nam JH, Oh DH, Park Y. Erythrocyte alpha-linolenic acid is associated with the risk for mild dementia in Korean elderly. Nutr Res. 2010;30(11):756-761.

4. Cherubini A, Andres-Lacueva C, Martin A, Lauretani F, Iorio AD, Bartali B, Corsi A, et al. Low plasma N-3 fatty acids and dementia in older persons: the InCHIANTI study. J Gerontol A Biol Sci Med Sci. 2007;62(10):11201126.

5. Roberts RO, Cerhan JR, Geda YE, Knopman DS, Cha RH, Christianson TJ, Pankratz VS, et al. Polyunsaturated fatty acids and reduced odds of MCI: the Mayo Clinic Study of Aging. J Alzheimers Dis. 2010;21(3):853-865.

6. Schaefer EJ, Bongard V, Beiser AS, Lamon-Fava S, Robins SJ, Au R, Tucker KL, et al. Plasma phosphatidylcholine docosahexaenoic acid content and risk of dementia and Alzheimer disease: the Framingham Heart Study. Arch Neurol. 2006;63(11):1545-1550.

7. Huang TL, Zandi PP, Tucker KL, Fitzpatrick AL, Kuller LH, Fried LP, Burke GL, et al. Benefits of fatty fish on dementia risk are stronger for those without APOE epsilon4. Neurology. 2005;65(9):1409-1414.

8. Morris MC, Evans DA, Bienias JL, Tangney CC, Bennett DA, Wilson RS, Aggarwal N, et al. Consumption of fish and n-3 fatty acids and risk of incident Alzheimer disease. Arch Neurol. 2003;60(7):940-946.

9. Morris MC, Brockman J, Schneider JA, Wang Y, Bennett DA, Tangney CC, van de Rest O. Association of Seafood Consumption, Brain Mercury Level, and APOE epsilon4 Status With Brain Neuropathology in Older Adults. JAMA. 2016;315(5):489-497.

10. van de Rest O, Wang Y, Barnes LL, Tangney C, Bennett DA, Morris MC. APOE epsilon4 and the associations of 
seafood and long-chain omega-3 fatty acids with cognitive decline. Neurology. 2016;86(22):2063-2070.

11. Lopez LB, Kritz-Silverstein D, Barrett Connor E. High dietary and plasma levels of the omega-3 fatty acid docosahexaenoic acid are associated with decreased dementia risk: the Rancho Bernardo study. J Nutr Health Aging. 2011;15(1):25-31.

12. Tully AM, Roche HM, Doyle R, Fallon C, Bruce I, Lawlor B, Coakley D, et al. Low serum cholesteryl ester-docosahexaenoic acid levels in Alzheimer's disease: a casecontrol study. Br J Nutr. 2003;89(4):483-489.

13. Conquer JA, Tierney MC, Zecevic J, Bettger WJ, Fisher RH. Fatty acid analysis of blood plasma of patients with Alzheimer's disease, other types of dementia, and cognitive impairment. Lipids. 2000;35(12):1305-1312.

14. Whalley LJ, Deary IJ, Starr JM, Wahle KW, Rance KA, Bourne VJ, Fox HC. n-3 Fatty acid erythrocyte membrane content, APOE varepsilon4, and cognitive variation: an observational follow-up study in late adulthood. Am J Clin Nutr. 2008;87(2):449-454.

15. Nishihira J, Tokashiki T, Higashiuesato Y, Willcox DC, Mattek N, Shinto L, Ohya Y, et al. Associations between Serum Omega-3 Fatty Acid Levels and Cognitive Functions among Community-Dwelling Octogenarians in Okinawa, Japan: The KOCOA Study. J Alzheimers Dis. 2016;51(3):857-866.

16. Ammann EM, Pottala JV, Harris WS, Espeland MA, Wallace R, Denburg NL, Carnahan RM, et al. omega-3 fatty acids and domain-specific cognitive aging: secondary analyses of data from WHISCA. Neurology. 2013;81(17):1484-1491.

17. Phillips MA, Childs CE, Calder PC, Rogers PJ. Lower omega-3 fatty acid intake and status are associated with poorer cognitive function in older age: A comparison of individuals with and without cognitive impairment and Alzheimer's disease. Nutr Neurosci. 2012;15(6):271-277.

18. Feart C, Torres MJ, Samieri C, Jutand MA, Peuchant E, Simopoulos AP, Barberger-Gateau P. Adherence to a Mediterranean diet and plasma fatty acids: data from the Bordeaux sample of the Three-City study. Br J Nutr. 2011;106(1):149-158.

19. Kroger E, Verreault R, Carmichael PH, Lindsay J, Julien P, Dewailly E, Ayotte P, et al. Omega-3 fatty acids and risk of dementia: the Canadian Study of Health and Aging. Am J Clin Nutr. 2009;90(1):184-192.

20. Devore EE, Grodstein F, van Rooij FJ, Hofman A, Rosner B, Stampfer MJ, Witteman JC, et al. Dietary intake of fish and omega-3 fatty acids in relation to long-term dementia risk. Am J Clin Nutr. 2009;90(1):170-176.

21. Samieri C, Feart C, Letenneur L, Dartigues JF, Peres K, Auriacombe S, Peuchant E, et al. Low plasma eicosapentaenoic acid and depressive symptomatology are independent predictors of dementia risk. Am J Clin Nutr. 2008;88(3):714-721.

22. Boespflug EL, McNamara RK, Eliassen JC, Schidler MD, Krikorian R. Fish Oil Supplementation Increases EventRelated Posterior Cingulate Activation in Older Adults with Subjective Memory Impairment. J Nutr Health Aging. 2016;20(2):161-169.
23. Phillips MA, Childs CE, Calder PC, Rogers PJ. No Effect of Omega-3 Fatty Acid Supplementation on Cognition and Mood in Individuals with Cognitive Impairment and Probable Alzheimer's Disease: A Randomised Controlled Trial. Int J Mol Sci. 2015;16(10):24600-24613.

24. Eriksdotter M, Vedin I, Falahati F, Freund-Levi Y, Hjorth E, Faxen-Irving G, Wahlund LO, et al. Plasma Fatty Acid Profiles in Relation to Cognition and Gender in Alzheimer's Disease Patients During Oral Omega-3 Fatty Acid Supplementation: The OmegAD Study. J Alzheimers Dis. 2015;48(3):805-812.

25. Geleijnse JM, Giltay EJ, Kromhout D. Effects of n-3 fatty acids on cognitive decline: a randomized, double-blind, placebo-controlled trial in stable myocardial infarction patients. Alzheimers Dement. 2012;8(4):278-287.

26. Sinn N, Milte CM, Street SJ, Buckley JD, Coates AM, Petkov J, Howe PR. Effects of n-3 fatty acids, EPA v. DHA, on depressive symptoms, quality of life, memory and executive function in older adults with mild cognitive impairment: a 6-month randomised controlled trial. Br J Nutr. 2012;107(11):1682-1693.

27. Irving GF, Freund-Levi $\mathrm{Y}$, Eriksdotter-Jonhagen $\mathrm{M}$, Basun H, Brismar K, Hjorth E, Palmblad J, et al. Omega-3 fatty acid supplementation effects on weight and appetite in patients with Alzheimer's disease: the omega-3 Alzheimer's disease study. J Am Geriatr Soc. 2009;57(1):11-17.

28. van de Rest O, Geleijnse JM, Kok FJ, van Staveren WA, Dullemeijer C, Olderikkert MG, Beekman AT, et al. Effect of fish oil on cognitive performance in older subjects: a randomized, controlled trial. Neurology. 2008;71(6):430438.

29. Freund-Levi Y, Basun H, Cederholm T, Faxen-Irving G, Garlind A, Grut M, Vedin I, et al. Omega-3 supplementation in mild to moderate Alzheimer's disease: effects on neuropsychiatric symptoms. Int J Geriatr Psychiatry. 2008;23(2):161-169.

30. Kulzow N, Witte AV, Kerti L, Grittner U, Schuchardt JP, Hahn A, Floel A. Impact of Omega-3 Fatty Acid Supplementation on Memory Functions in Healthy Older Adults. J Alzheimers Dis. 2016;51(3):713-725.

31. Chiu CC, Su KP, Cheng TC, Liu HC, Chang CJ, Dewey ME, Stewart R, et al. The effects of omega-3 fatty acids monotherapy in Alzheimer's disease and mild cognitive impairment: a preliminary randomized double-blind placebo-controlled study. Prog Neuropsychopharmacol Biol Psychiatry. 2008;32(6):1538-1544.

32. Hashimoto M, Kato S, Tanabe Y, Katakura M, Mamun AA, Ohno M, Hossain S, et al. Beneficial effects of dietary docosahexaenoic acid intervention on cognitive function and mental health of the oldest elderly in Japanese care facilities and nursing homes. Geriatr Gerontol Int. 2016.

33. Yurko-Mauro K, McCarthy D, Rom D, Nelson EB, Ryan AS, Blackwell A, Salem N, Jr., et al. Beneficial effects of docosahexaenoic acid on cognition in age-related cognitive decline. Alzheimers Dement. 2010;6(6):456-464.

34. Quinn JF, Raman R, Thomas RG, Yurko-Mauro K, Nelson EB, Van Dyck C, Galvin JE, et al. Docosahexaenoic acid supplementation and cognitive decline in Alzheimer 
disease: a randomized trial. JAMA. 2010;304(17):19031911.

35. McGeer PL, Itagaki S, Tago H, McGeer EG. Reactive microglia in patients with senile dementia of the Alzheimer type are positive for the histocompatibility glycoprotein HLA-DR. Neurosci Lett. 1987;79(1-2):195-200.

36. Perlmutter LS, Barron E, Chui HC. Morphologic association between microglia and senile plaque amyloid in Alzheimer's disease. Neurosci Lett. 1990;119(1):32-36.

37. Frautschy SA, Yang F, Irrizarry M, Hyman B, Saido TC, Hsiao K, Cole GM. Microglial response to amyloid plaques in APPsw transgenic mice. Am J Pathol. 1998;152(1):307-317.

38. Dickson DW. Microglia in Alzheimer's disease and transgenic models. How close the fit? Am J Pathol. 1999;154(6):1627-1631.

39. Stalder M, Phinney A, Probst A, Sommer B, Staufenbiel M, Jucker M. Association of microglia with amyloid plaques in brains of APP23 transgenic mice. Am J Pathol. 1999;154(6):1673-1684.

40. Selkoe DJ. The origins of Alzheimer disease: $a$ is for amyloid. JAMA. 2000;283(12):1615-1617.

41. Vassar R. BACE1: the beta-secretase enzyme in Alzheimer's disease. J Mol Neurosci. 2004;23(1-2):105-114.

42. Thornton E, Vink R, Blumbergs PC, Van Den Heuvel C. Soluble amyloid precursor protein alpha reduces neuronal injury and improves functional outcome following diffuse traumatic brain injury in rats. Brain Res. 2006;1094(1):38-46.

43. Cheng H, Vetrivel KS, Gong P, Meckler X, Parent A, Thinakaran G. Mechanisms of disease: new therapeutic strategies for Alzheimer's disease - targeting APP processing in lipid rafts. Nat Clin Pract Neurol. 2007;3(7):374-382.

44. Yang X, Sheng W, Sun GY, Lee JC. Effects of fatty acid unsaturation numbers on membrane fluidity and alphasecretase-dependent amyloid precursor protein process- ing. Neurochem Int. 2011;58(3):321-329.

45. Faxen-Irving G, Freund-Levi Y, Eriksdotter-Jonhagen M, Basun H, Hjorth E, Palmblad J, Vedin I, et al. Effects on transthyretin in plasma and cerebrospinal fluid by DHArich $\mathrm{n}-3$ fatty acid supplementation in patients with Alzheimer's disease: the OmegAD study. J Alzheimers Dis. 2013;36(1):1-6.

46. Hjorth E, Zhu M, Toro VC, Vedin I, Palmblad J, Cederholm T, Freund-Levi Y, et al. Omega-3 fatty acids enhance phagocytosis of Alzheimer's disease-related amyloidbeta42 by human microglia and decrease inflammatory markers. J Alzheimers Dis. 2013;35(4):697-713.

47. Wang X, Hjorth E, Vedin I, Eriksdotter M, Freund-Levi Y, Wahlund LO, Cederholm T, et al. Effects of n-3 FA supplementation on the release of proresolving lipid mediators by blood mononuclear cells: the OmegAD study. J Lipid Res. 2015;56(3):674-681.

48. Serini S, Bizzarro A, Piccioni E, Fasano E, Rossi C, Lauria A, Cittadini AR, et al. EPA and DHA differentially affect in vitro inflammatory cytokine release by peripheral blood mononuclear cells from Alzheimer's patients. Curr Alzheimer Res. 2012;9(8):913-923.

49. Vedin I, Cederholm T, Freund-Levi Y, Basun H, Hjorth E, Irving GF, Eriksdotter-Jonhagen M, et al. Reduced prostaglandin F2 alpha release from blood mononuclear leukocytes after oral supplementation of omega3 fatty acids: the OmegAD study. J Lipid Res. 2010;51(5):11791185 .

50. Nelson TJ, Cui C, Luo Y, Alkon DL. Reduction of betaamyloid levels by novel protein kinase C(epsilon) activators. J Biol Chem. 2009;284(50):34514-34521.

51. Vedin I, Cederholm T, Freund Levi Y, Basun H, Garlind A, Faxen Irving G, Jonhagen ME, et al. Effects of docosahexaenoic acid-rich n-3 fatty acid supplementation on cytokine release from blood mononuclear leukocytes: the OmegAD study. Am J Clin Nutr. 2008;87(6):1616-1622. 